\title{
Martin Krygier's Passion for the Rule of Law (and His Virtues)
}

\author{
Nick Cheesman ${ }^{1,2} \cdot$ Ronald Janse ${ }^{3}$
}

Published online: 5 November 2019

(C) The Author(s) 2019

\begin{abstract}
Why did Martin Krygier become a rule of law guy? This Introduction to a Special Issue of the Hague Journal on the Rule of Law, which consists of 33 short essays celebrating Krygier as a colleague, mentor and friend, discusses some of the factors which prompted him to develop a distinct and influential body of work on the rule of law over the past three decades: the rule of law revival, especially in Central and Eastern Europe; his involvement with Philip Selznick; and his dialogue with other prominent theorists, including Gianluigi Palombella and Jeremy Waldron. The Introduction gives a sense of the importance of Krygier's personal background and history, and it also discusses some of the key features of his theory, and how these have developed over the past decades.
\end{abstract}

\section{Introducing Martin Krygier}

Martin Krygier should need no introduction to anyone who has read widely on the rule of law. For three decades Krygier has been a prolific author and sought-after speaker on the subject, and on cognate topics: political morality, public values, civility and decency, to name a few. That he succeeds in persuading many in his audiences to think more about why we might want the rule of law is not only because of the cadences of his prose or the timbre of his voice, though these are noteworthy. Nor is it only because he is a practiced communicator, though this certainly helps. It is also because Krygier is at his best when talking things through, sometimes vehemently, hearing out others deserving of heed, whether like-minded folks or dissenting ones, and thinking about things worthy of cogitation.

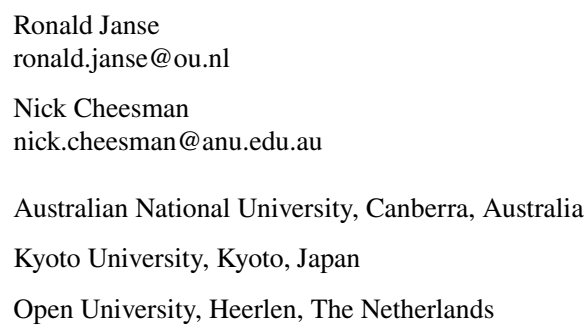




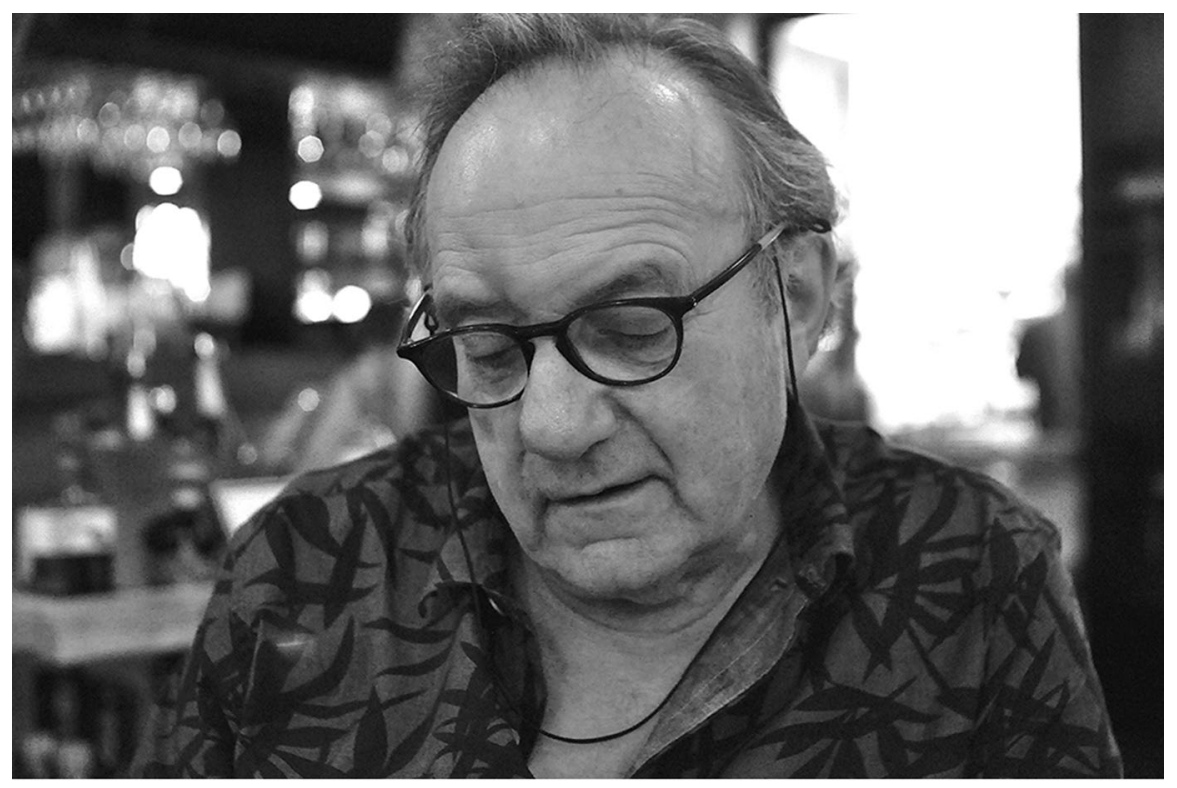

Martin Krygier 
No doubt it is in part because Martin Krygier is such a pleasure to converse with that colleagues around the world willingly took time at relatively short notice to write essays recognizing his influence on rule-of-law scholarship, and on them. Bojan Bugarič suggested a special issue to mark Krygier's seventieth birthday this February 2019, celebrating him as a friend, mentor and public intellect. Not all good suggestions are followed. Happily, this one was. That Krygier's long-time PolishAustralian companions Adam Czarnota and Wojciech Sadurski joined the organizing team for this Special Issue of the Hague Journal on the Rule of Law made enrolling contributors even easier.

The result is something of an embarrassment of riches. Krygier's circle of esteem is as large as his generosity is abundant. It skirts continents. It is diverse. In evidence, assembled are essays from students of the humanities and social sciences, variously theorists and empiricists, with interests ranging from ancient Greece to transitioning Myanmar. Among them are observers as well as practitioners of the rule of law. Together they span three generations. Some cut their intellectual teeth in the days of the Cold War, others in the years that followed the Soviet bloc's breakup. Still others have joined the conversation in the last decade. All speak of how Krygier's scholarship has continued to stimulate, and his companionship, enliven.

As the essays rolled in, it dawned on us that we would need to introduce Martin Krygier after all. We learned many things from the essayists about how he has influenced them that we did not know. Reading his abundant writings alongside theirs, we caught new glimpses of his passion for the rule of law, and how he acquired it. And so this Introduction has two tasks. The first is to give a sense of Krygier's journey: not to retrace it, but to convey something of who and what has agitated him to write so much and speak so often on the rule of law. In discharging this task we take guidance from Jeremy Waldron's prefatory remarks, putting emphasis on the virtues of Krygier's approach, and on those of the man himself.

The second task of the Introduction is to show how Martin Krygier has enriched the lives of others, among them, us. Among them too are the contributors to this Special Issue. We remark on their contributions throughout this Introduction, not to force consensus about the meaning or significance of Krygier's work on the rule of law, but to elicit more reasoned and perhaps more impassioned dialogue about it. And that, we are confident Martin will agree, is a good thing to have.

\section{Congenital Commitments}

Martin Krygier's first influential article on the rule of law appeared in the autumn 1990 issue of Law and Social Inquiry. He wrote it while on leave from teaching at the University of New South Wales, in Sydney, during a second visitorship at the University of California, Berkeley. In it he addressed the relationship between Karl Marx's thought and 'really existing socialism', which had just collapsed in Central and Eastern Europe, and would do so imminently in the Soviet Union. ${ }^{1}$ For

\footnotetext{
${ }^{1}$ Krygier (1990a), p. 634.
} 
communist totalitarianism to justify itself by reference to Marx and his thought was, Krygier argued, no inconsistency. Marxism is uninterested in mediating institutions, in restraining huge ambitions, or in protecting humans against their own species. Krygier, borrowing from Weber, saw selective affinities between Marx's thought and really existing socialism. Both were inimical to the rule of law.

'Marxism and the Rule of Law' drew lively responses from eminent commentators. Some found grounds for agreement in aspects of its reasoning and method. Others found little or none. Richard Abel described its 'really existing socialism' line as 'a form of McCarthyite red-baiting that has no place in academic discourse'. ${ }^{2}$ Krygier responded to Abel's classing of the Soviet Union as an instance not of communist totalitarianism but of 'state capitalism' by asking whether it would be adequate for someone despairing at 'really existing liberalism' to class the US as a case of 'corporate communism' instead. ${ }^{3}$ John Comaroff said that while Krygier wrote against Marx, like him Krygier obviously knew 'how to start an argument' and relished its prospect. ${ }^{4}$

There was something to that. Krygier had, as he later wrote admiringly of the moral philosopher Raimond Gaita, 'come to these skirmishes well provisioned' 5 The LSI piece might have been his first substantive article on the rule of law's relation to an ideological other, but it had been years in the making. Some of its arguments Krygier had rehearsed in an excoriating 1983 review of Marxism and Law, whose author, Hugh Collins, he describes as being strangely detached 'from the real problems his analysis touches on', not least of all in his closing chapter concerning class struggle and the rule of law. ${ }^{6}$ In his review, Krygier quotes three Australian émigré disciples of Georg Lukacs on 'really existing socialism', that, 'Faced with Eastern European societies, Western socialism cannot adopt the attitude of assuring everyone that the practical social project it represents has nothing to do with the realities of those societies. ${ }^{7}$ Enough said.

Or perhaps not, since in many ways the 1990 article had been a lifetime in the making. If it had a polemical quality, it was not just for polemics' sake. It was born of Krygier's self-described 'visceral aversion to untempered power', to which Terence Halliday refers in his essay, and his congenital concern with how power could be held in check. 'As it happens,' Krygier later wrote in his book of collected essays, Civil Passions, 'I was born, indeed in my particular case conceived, an anti-communist. ${ }^{8}$ Martin's parents, Roma and Richard, were Polish Jews who married in January 1939. They lost each other after the German invasion of Poland later that year but managed to reunite in Lithuania during 1940. Despite the Soviet army seizing their passports, they were able to take the Trans-Siberian railway to Vladivostok,

\footnotetext{
2 Abel (1990), p. 688.

3 Krygier (1990b), p. 715.

${ }^{4}$ Comaroff (1990), p. 671.

5 Krygier (2011a), p. 122.

6 Krygier (1983), p. 243.

${ }^{7}$ Fehér et al. (1983), p. 44, in ibid., p. 246.

8 Krygier (2005a), p. 132.
} 
from where they went to Japan. They spent a year working for the Polish Relief Committee, attached to the Polish Embassy, and came to Australia more or less by accident in November 1941. Canada had been their planned destination, but in Sydney they stayed.

Nazis killed Martin Krygier's maternal grandparents and uncle before he was born. His mother had earlier participated in leftist politics, but her and her husband's brief experience with the Soviets convinced them that communism was not going to be better than Nazism. Later Richard Krygier would say: 'I was anti-Nazi before the war; I'm anti-communist today. I haven't changed. ${ }^{9}$ In the meantime he founded the Australian Association for Cultural Freedom. He contacted many prominent intellectuals overseas, including Irving Kristol, Malcolm Muggeridge and Stephen Spender. Some he brought to Australia for lectures, seminars and public discussions. He energetically organized cultural events, including a production of Darkness at Noon, at the Independent theatre. Most importantly, he established a literary magazine, Quadrant, whose first issue appeared at the end of 1956. In a short time Quadrant occupied the apex of conservative intellectual interchange in Australia. Distinguished authors, journalists, historians and social scientists took turns as editors. Prominent theologians, jurists, poets, comedians and politicians joined the ranks of contributors. ${ }^{10}$ Krygier senior worked tirelessly behind the scenes to keep the magazine financially afloat and intellectually on target. Late in life he wrote a popular column on his readings from books and serials received from abroad, routinely interspersed with quotations and translations of commentary and news from French, German, Polish and Russian periodicals.

Martin was deeply influenced by his parents' experiences: they informed, he wrote in 1997, 'the way I think about things, what I think about and-above allwhat I think matters'. ${ }^{11}$ But he did not just imbibe. He pushed himself to render their ideas and experiences his own, writing another chapter, as Lidia Rodak puts it in her contribution to this Special Issue, in his family history. He took pride in his linguistic and cultural heritage, learning Polish and cherishing his cultural hybridity. He made 'an obsessive attempt' in his late teens and early twenties to gain an understanding of totalitarian regimes-not easy for 'a young, comfortable, suburban Sydneysider' who lived near Bondi Beach. ${ }^{12}$ This effort led the youthful Martin to make what John Braithwaite considers to be, in his essay, some bad choices and bad friends. But if in youth the two were on opposite sides of the barricades then in maturity Braithwaite declares himself a convert to Krygier's congenially hybrid 'conservative-liberal-republican-communitarian-social-democratic International', and applauds his companion's 'genuinely independent intellectual spirit'.

In forging this spirit, Martin Krygier was fortunate to have not only his father as a model of fierce independent mindedness. At the Australian National University, he wrote a thesis on Marxism and bureaucracy that another cultural hybrid,

\footnotetext{
9 In ibid., p. 14.

10 Coleman (1986).

11 Krygier (2005a), p. 19.

12 Ibid., p. 151.
} 
the Marxist philosopher and German Jewish émigré Eugene Kamenka, supervised. Krygier submitted his thesis in 1979 while lecturing on jurisprudence at the University of Sydney. On the ANU's campus Krygier found a model of frank speaking in the classicist and Sinologist, Pierre Ryckmans, who wrote vociferously under the pen name Simon Leys. Outraged at atrocities in Mao Zedong's China, Ryckmans addressed his topics with a conviction that impressed Krygier. Years later, in the first of his 1996 Boyer Lectures on the Australian national broadcaster, Ryckmans stressed that a genuine university must be anchored in values that begin but do not end with a concern for the truth. The realization of truth, he noted, quoting Hannah Arendt, does not come at the end of thinking: it is the starting point for it. ${ }^{13}$ The saying 'to see is to believe', he added, has things the wrong way around: to believe is to see. True belief is not blind. Sight depends on it.

Ryckmans probably did not have Martin Krygier in mind when he spoke. Nevertheless, he captured how Krygier's belief in the sometimes maligned value of civility gave him a locus from which to realize why the rule of law matters. Deval Desai, in his essay for our collection, captures it too. In the first of his own Boyer Lectures, the year after Ryckmans', Krygier told his listenership that he had 'no systematic doctrine to sell', only 'some values to commend'. ${ }^{14}$ These values inhere to certain truths. They include that a civil society, whose members don't generally love each other but do routinely trust one another, is better than an uncivil one, in which they do neither; and, that a decent society, one that in Avishai Margalit's sense does not humiliate people, is better still, because its members take pride in praiseworthy acts, and show remorse for shameful ones. ${ }^{15}$ Australian society circa 1997 was more civil and arguably more decent than many others in the world-with the significant exception of how it treated, and has since continued to treat, aboriginal peoples; a topic on which Krygier has spoken and written forthrightly. ${ }^{16}$ It might just as easily have been much less civil than it was. Yet it was not, and that mattered. What made it so? The answer to that question, Krygier suggested, could be reached by way of another: compared to what? Where does one look to compare the quality of justice and adequacy of institutions here with those over there? What makes the one more civil than the other?

Professional comparativists seek answers to such questions via their formal methods for selecting cases to compare. Krygier had none of their training; however, he did have two countries that he knew well enough to set side by side and ask these and other questions about with some confidence. These were Australia and Poland. But whereas he had come of age in the former, he had to travel to the latter to know it. Krygier first went to Poland in 1985 . Writing shortly afterwards he remarked that while he had already heard about most of what he observed there, he 'had not felt it'. ${ }^{17}$ For someone who both thinks and feels his way through problems, being in

\footnotetext{
13 Ryckmans (1996), pp. 6-7.

14 Krygier (1997a).

15 Margalit (1996).

16 See for instance Krygier (1997b).

17 Krygier (2005a), p. 247.
} 
Poland was, he recalled later, 'a profound experience on many levels, moral, intellectual, psychological', to which he added,

Central but not the whole of it was to come into a world of serious and brave people who seemed to think the way I did. For although I hadn't suffered anything significant from being a pariah and son of pariah among Australian political students and intellectuals... I found it gratifying to be among people I so respected, whose attitudes to communism and to precious liberal values, born of a negative experience I felt I knew intimately though I'd suffered none of it, seemed to chime with my own. ${ }^{18}$

The feeling of fellowship that Krygier encountered in Poland first in 1985 and again in 1989 as a guest of the Nicolaus Copernicus University, just months before really existing socialism started to disintegrate, affirmed to him that he had been right to put his faith in those values that he would later commend to the Australian public. It put wind in his sails. If gentle gusts supplied by friends and colleagues in Warsaw and Torun carried Krygier towards 'Marxism and the Rule of Law', then winds of change in Central and Eastern Europe, and in the academy, were to carry him well beyond it.

\section{Becoming a Rule-of-Law Guy}

Perhaps because the crux of the 'Marxism' article's argument lay in the relationship between communist ideology and practices in its name, about which he had been thinking for well over a decade, Krygier's 1990 account of the rule of law was pretty standard. It consisted of three elements, each a 'crucial and historically rare mode of restraint on power by law'. ${ }^{19}$ The rule of law in this account was, firstly, government by law: the exercise of governmental power by means of laws that are open, publicly available, understandable, stable, general and made known in advance. Secondly, it was government under law: a situation in which even high officials are confined and confinable to legal rules, their actions open to legal challenge. Thirdly, it required respect for rights, which protect individuals against interference. With this last element Krygier distanced himself from Joseph Raz's defence of a thin conception of the rule of law. ${ }^{20}$ For Krygier, government both by and under law was necessary though insufficient for the rule of law.

Although not an original contribution to the rule-of-law literature, 'Marxism and the Rule of Law' did contain signposts pointing towards Krygier's later work. One indicated the rule of law's purpose: to reduce arbitrariness. This is, of course, the usual fare, but Krygier has since made more of a meal of it than most others. Gianluigi Palombella is particularly attentive to this aspect of Krygier's thinking in his contribution to this Special Issue. Another signpost pointed to non-legal,

\footnotetext{
18 Krygier (2014a), p. 51.

19 Krygier (1990a), p. 642.

20 Raz (1979).
} 
social preconditions for the rule of law: that government under law requires a general attitude that officials at the highest levels are bound by legal rules, which in societies with the rule of law is 'commonly so deeply embedded an achievement that no one notices it as an achievement. It is simply taken as the way to behave. ${ }^{21}$ A further signpost was that the rule of law is denoted by conditions in which law plausibly counts as a restraint on really existing power. That presupposes 'a widespread assumption within the society that law matters and should matter'. ${ }^{22}$ This is not something that can be decreed; it comes largely from within, though it can be encouraged from without. Hence the need for tradition, though he did not emphasize it at this juncture, both as a site of change and as a central feature of law. ${ }^{23}$ Lastly, for our purposes, he underscored that the rule of law was not a panacea. But nor was its promise illusory. Though it was no guarantee of a civil society, without it there could be no civil society to speak of.

Nevertheless, Krygier had quite a way to go before he would arrive at his teleological conception of the rule of law, which we discuss later. At this juncture, Krygier's rule of law juxtaposed with really existing socialism was about restraint of governmental power, not other forms of power. Moreover, it was still conceived primarily in terms of restraint through law. So although the 'Marxism' exchange drew quite a lot of interest, there was not that much in it to suggest that its protagonist was to become one of the most productive and original communicators on the rule of law of our time. Yet as we now know, the 'complex virtues and limitations of the rule of law' were, as Krygier wrote in Civil Passions some 15 years later, soon to be among his 'major academic, indeed life, concerns'. ${ }^{24}$ By this time he had published a slew of articles and chapters in which he had re-examined classic accounts of the rule of law by the likes of Dicey and Fuller, and had started to develop his own distinctive take on it. Many more would follow.

So why did Martin Krygier become 'a rule of law guy' ${ }^{25}$ What sustained his interest in this political ideal, one that by his own admission does not tend to arouse excitement or passion in others? Answers to these questions seem to lie in a blend of three factors: one, situational, two, in parts personal and intellectual. The first was what Thomas Carothers pronounced as 'the rule-of-law revival' that followed the collapse of communism. ${ }^{26}$ The second was Krygier's involvement with the sociologist Philip Selznick. The third was his ongoing dialogue with other prominent theorists, among them Gianluigi Palombella and Jeremy Waldron. The first factor prompted Krygier to rethink his notion of the rule of law, the second provided him with key insights and inspired him to speak and write more vigorously for those values that he had throughout his life held dear, and the third provoked him to clarify,

\footnotetext{
${ }^{21}$ Krygier (1990a), p. 643.

22 Ibid., p. 646.

23 See Krygier (1986).

24 Krygier (2005a), p. xi.

25 Krygier (2013).

26 Carothers (1998).
} 
sharpen and refine his views on the rule of law and why it matters. The next three sections of the Introduction address each of these in turn.

\section{Theorist of the Rule-of-Law Revival}

In 2001, a few years on from Carothers' pronouncement, Martin Krygier reflected on the decade after the Berlin Wall fell. ${ }^{27}$ He noted that before 1989 the rule of law had been shorthand for some virtues of liberalism, in contrast to how power was exercised under communism—-much as he had done in his 'Marxism' article. There was no need then to spend a lot of time re-examining orthodox conceptions of the rule of law that Dicey, Fuller and others had put about. Of course there had been debate on whether the rule of law is distinct from or encompassing of democracy, or of human rights - the topic of Catherine Renshaw's essay. Raz's position that 'the rule of good law' was a useless idea had its supporters. ${ }^{28}$ Others endorsed Ronald Dworkin's rights-based conception. ${ }^{29}$ Yet in many ways debate continued to turn on questions of what the rule of law constituted: many rules or fewer, more principles or less, larger institutions or smaller. The list of elements necessary for the rule of law might be longer or shorter, its items greater or lesser in number, but the task remained to figure out what the rule of law is made up of - what its anatomy isand then, perhaps, how it might be possible to get it.

All this changed with the rule-of-law revival. Krygier was uncommonly well prepared to think through events of the 1990s in Central and Eastern Europe. Not that he had an epiphany. Originally he took for granted that the rule of law conceptualized 'anatomically', as he later preferred to say, could and perhaps should be exported to post-communist countries. 'There was a time, 1989 to be precise,' he recalled subsequently, "when I assumed the rule of law... was what the world needed and that it was well captured in Lon Fuller's "internal morality" or something like it. And so it seemed that in all the excitement of the collapse of communism, this was a product ripe for export. ${ }^{30}$ People in post-communist countries did, in his experience, really want the rule of law. Experts and donors from abroad were offering to deliver it to them. The frenzied writing of new constitutions and laws, hasty establishment of constitutional courts and ombudsmen, brisk training of judges and lawyers were not foolhardy activities. They were motivated by sincere desires to break with the past, by authentic hopes to make a better future. Krygier shared those desires, sympathized with those hopes.

But like others observing the rule-of-law revival, or experiencing it first hand, he soon had second thoughts. Attempts to implant the rule of law in unfamiliar soil' seemed to have disappointing or adverse results. ${ }^{31}$ Early shortcomings could

\footnotetext{
27 Krygier (2001a, b).

28 Raz (1979), p. 211.

29 Dworkin (1985).

30 Krygier (2009), p. 45.

31 Krygier (2001a), p. 2.
} 
be put down to a surfeit of enthusiasm or a deficit of knowledge. But the same story seemed to play out time and again. The revival, as Carothers later wrote, evidently would not achieve what its promoters promised it would-though as Veronica Taylor points out in her essay, the kind of rule-of-law mythologizing that went with the revival has a certain utility that helps explain why it persists up until today, even though practitioners are well aware of gaps between their claims about the rule of law and reality.

Krygier started thinking more deliberately about why things were not going so well for the rule-of-law revival, often in dialogue with colleagues and doctoral candidates from the region, as Dimitry Kochenov and Renata Uitz fondly recall in their essays. His goal was not, as was commonplace at this time, to put right rule-oflaw projects gone wrong. Nor was it to offer a critique of what some, like Richard Sannerholm in his essay, label the rule-of-law industry. Yes, Krygier sometimes criticized. However, he also cautioned against reacting to off-the-shelf designs for the rule of law by overstating the uniqueness of each country, which would make it 'hard to know when purposes are achieved or criticism is appropriate'. ${ }^{32}$ But the back-and-forth over the terms of engagement for rule-of-law projects did not matter to Krygier all that much. His main concern lay elsewhere, with whether or not the sources of disappointment in the rule of law's ostensible revival were in fact what its partisans assumed they were. Invoking Gertrude Stein, he proposed to pivot from questions about the ways rule-of-law people had addressed the problems they had confronted up until then, to questions about the ways they had 'framed and thought about those problems to begin with'. ${ }^{33}$

This pivot brought Krygier to articulate more sharply his by now well-known distinction between teleology and anatomy, or morphology, of the rule of law: first to ask why we would bother with it, and only then, how and with what it might be obtained; to start, like E.P. Thompson, with valued ends, 'rather than with some contingent set of legal means'. ${ }^{34}$ Though he demurred over whether or not his approach might be 'less appropriate for understanding elements of the rule of law where it is established, than it might be for seeking to introduce it where it is not', the cause of difficulties in both circumstances, Krygier surmised, was the same: that 'we lack, as a matter of principle rather than epistemological shortcoming, universal legalinstitutional prescriptions for the rule of law. The reasons for that, in turn, have to do with social complexity rather than lack of legal ingenuity. ${ }^{35}$

In sum, by the 2000s Martin Krygier had emerged not as a general theorist of the rule of law, but as a theorist of the rule of law in the wake of its nascent revival; a theorist of both really existing and really absent rule of law since the late 1980s, who diligently pursued his own questions of what we can learn about the rule of law from places where it is absent, compared to those where it imperfectly exists. This manner of going about things set Krygier's mode of inquiry apart from most of

\footnotetext{
32 Krygier (2005b), p. 273

33 Krygier, (2001a), p. 2.

${ }^{34}$ Krygier (2016a), p. 487.

35 Krygier (2009), p. 47.
} 
his contemporaries. Tamanaha, Palombella and Waldron have developed their work predominantly in response to challenges to the rule of law in North America and Western Europe. ${ }^{36}$ Mainstream political scientists like Stephan Haggard or Barry Weingast have tended to concentrate 'on identifying measurable entities rather than exploring contested ambiguities of meaning' and avoid discussions about the relation of contemporary rule-of-law problems to social values. ${ }^{37}$ Martin Krygier did not shy away from this relation. Nor did he shy away from places where it could and should be discussed as a practical imperative as well as a philosophical problem.

Krygier was interested primarily in Poland and other countries in Central and Eastern Europe. By the 2000s he had published a string of papers as well as two coedited books with Czarnota and Sadurski on the rule of law in the region. ${ }^{38}$ In 2009 , two decades on from the collapse of really existing European communism, he edited a special issue of the Hague Journal on the Rule of Law (vol. 1, no. 2) on the topic. By then it seemed as if everything that urgently needed to be said about the rule of law in Poland and its neighbours had been said. But the rise of Jaroslaw Kaczynski since, along with Viktor Orbán in Hungary, has prompted Krygier to write with renewed urgency on the rule of law's thin institutionalization in Central and Eastern Europe, and to speak in support of embattled rule-of-law advocates in Poland who are, Miroslaw Wyrzykowski writes in his essay, today 'experiencing the unimaginable'. This Special Issue also contains an essay by Dimitry Kochenov on the European Commission's response to the anti-rule-of-law turn in Hungary and Poland, as well as reflections on the characteristics and causes of rule-of-law backsliding by Marcin Matczak, who likens anti-rule-of-law attitudes to anti-vaccination campaigns; by Jacek Kurczewski, who discusses how rule-of-law decline takes many different forms; and by Bojan Bugarič, who explores the limits of legal institutions in countering illiberal chicanery-to borrow Renata Uitz's expression. Adam Czarnota takes a contrary, more optimistic view in his essay, arguing that 'we are currently witnessing the process of the painful birth of a new approach to the rule of law' in Central and Eastern Europe.

The manner in which Krygier has gone about his inquiries into places where the rule of law is wanting has proven attractive not only to students of Poland and its neighbourhood. As the contents of this Special Issue reveal, his thinking has influenced others like Terence Halliday, on China, Melissa Crouch, on Myanmar, a country where Krygier in recent years led a constitutional democracy project, and Mark Massoud, on Sudan and Somalia, whose essay tracks the relationship between the rule of law and religion in both Judeo-Christian and Islamic societies. Krygier's work also appeals to people who are interested in thinking about the rule of law not only in terms of the global rule-of-law revival and what remains in its wake, but to do so on terms that are both philosophical and sociological. That is because Krygier wants a social science of the rule of law 'that does not quite yet exist' so as to bring

\footnotetext{
36 A part of Brian Tamanaha's rich and extensive work on the rule of law is a prominent exception. See Tamanaha (2011a, b)

37 Krygier (2016a), p. 222.

38 Czarnota et al. (2005, 2006).
} 
together, through these kinds of inquiries, norms and facts that conventionally are held apart. ${ }^{39}$ Again we can hear echoes of his 'Marxism' argument in this, resonating now not in old ideological fights, but in questions we ask of the rule of law itself.

But we get ahead of ourselves. To understand how Krygier blends the philosophical and sociological in his approach to the rule of law, first we must take measure of his intellectual and moral debts to Philip Selznick.

\section{Philip Selznick}

If the rule-of-law revival provided an impetus for Martin Krygier to rethink the rule of law, then Philip Selznick inspired it. From Selznick, Krygier says, he 'learned a new language and way of speaking, as well as new thoughts and ways of thinking' about the rule of law, ways that worked against a tendency to polarize, which he 'had shared with both allies and opponents' in the old days. ${ }^{40}$ What he learned he learned well. When Krygier writes that Selznick's work has 'a strong and unifying temper... a coherent intellectual and moral character', he might as well be writing of his own. ${ }^{41}$ This is surely no coincidence. It is a testament to their connection. What brought them together? What made their relationship flourish?

Selznick had pioneered the law-and-society center at Berkeley in the tumult of the 1960s, and subsequently in the 1970s established the Jurisprudence and Social Policy (JSP) program there with the goal 'to link social sciences with jurisprudence, that is, the philosophical... ways of thinking about law'. ${ }^{42}$ Selznick went to Berkeley after making his name in organizational theory. For a time in the late 1930s he had been a Trotskyite. Decades before Krygier offered his own account of bureaucracy in Trotsky's analysis of Stalinism, Selznick had already gone beyond the Trotskyites' usual critique of bureaucracy, into the problem of reconciling formal organization with animating values: under which conditions are goals frustrated? Under which are ideals given 'life and hope' ${ }^{43}$ These questions led him to research that resulted in his seminal TVA and the Grass Roots. ${ }^{44}$

It was during his two stints in the JSP program, in 1985 and 1989-90, that Krygier befriended Selznick and his wife, Doris Fine. There was much in Selznick and his work for Krygier to like. But more than any particular aspect of Selznick's writing, it was his 'manner and style of thinking' that led Krygier to start doing research that culminated in 2012 with Philip Selznick: Ideals in the World ${ }^{45}$ The book is, as Krygier acknowledges in its opening pages, an appreciation. Krygier appreciates Selznick not only for what he contributed to theorizing about the rule

\footnotetext{
39 Krygier (2016b), p. 222.

40 Krygier (2012), p. 10.

41 Ibid., p. 5.

42 Ibid., p. 163.

43 Selznick (1992), p. x.

44 Selznick (1949).

45 Krygier (2012), p. 9.
} 
of law, though this is important. More to the point, as Krygier notes in the closing pages, his interest in Selznick was 'not merely for his particular subjects and what he had to say about them... but for the distinctive aspects of his ways of thought, his moral-intellectual character and sensibility'. ${ }^{46}$ Selznick embodied for Krygier a certain temperament. Of this, he wrote, on his mentor's death in 2010, that

Selznick's writings manifest a way of thinking that is also a way of feeling and, indeed, of being: there are of course arguments and evidence but there is also a matter of sensibility. It pervades his work and lends it an identifiable tone and character. This appears in a kind of pervasive judiciousness and thoughtfulness; a determination to accommodate complexity and not pretend that realities and choices are simpler or starker than they need be; in particular, an ability to recognize the existence of tensions and dynamics in social processes without apocalyptic overdramatization of them. ${ }^{47}$

This was certainly true of Selznick's writing on the sociology of law, for which his time at Berkeley is notable. There he wrote two books that had a lasting effect on Krygier's thinking about the rule of law. One, Law, Society and Industrial Justice, addressed the question of whether or not the rule-of-law ideal could be institutionally embodied in industrial relations. ${ }^{48}$ The second, with a former student, Philippe Nonet, was Law and Society in Transition. ${ }^{49}$ This book, Krygier has written, "in many ways might be taken to represent a manifesto for the JSP approach and in particular its commitment to ground legal philosophy in history and the social sciences, illuminate social science with philosophical attention to fundamental concepts, and focus them all on questions of policy relevance'. ${ }^{50}$ At its core was that fundamental concept with which we are here primarily concerned: the rule of law.

Selznick abridged the rule of law as "the "progressive" reduction of arbitrariness in law and its administration'. ${ }^{51}$ This is another pretty standard albeit pithy statement of the ideal. Krygier hardly needed Selznick to arrive at this point. Nor could he look to Selznick in order to get to the bottom of arbitrariness: late in life Selznick 'agreed that he had never tied it down conceptually'. ${ }^{52}$ Yet a number of themes in the older man's work on the rule of law deeply influenced the younger. Notwithstanding some differences of opinion between them that Krygier addresses in Ideals in the World, on which Sanne Taekema and David Lieberman write in this Special Issue, three of Selznick's recurrent themes reveal themselves in Krygier's own writings and talks.

First, Selznick insisted that the rule of law is not just a matter of legal rules and institutions but that it depends on social and political determinants that infuse rules and institutions with value. This is not as simple as it sounds. It is not just another

\footnotetext{
46 Ibid., p. 275.

47 Krygier (2009), p. 14; see Palombella (2010).

48 Selznick (1969).

49 Nonet and Selznick (2001).

50 Krygier (2012), p. 164.

51 Ibid., p. 145.

52 Ibid.
} 
way of saying that one has to take stock of what is happening somewhere to come to grips with the rule of law there. Rather, it obligates the rule-of-law researcher to get at "the inner life of organizations and the significance of "the embodiment of ideals in institutions". ${ }^{53}$ It follows that Selznick would argue that the rule of law as an ideal embodied to a greater or lesser extent in legal institutions 'must be a chief preoccupation of legal sociology'. 54

Coming from jurisprudence, Krygier has taken up the case for sociology of the rule of law on related but distinct terms from Selznick's. In calling for a social science of the rule of law 'which does not yet exist' he has by his own admission plagiarized or perhaps paid homage to Karol Sołtan, who used this expression in reference to Selznick and a number of others. ${ }^{55}$ But Krygier also has evoked Selznick's own appeal, late in life, for a 'humanist science', one that shares with legal realism a pragmatist concern to break down the pernicious dichotomy between facts and values.

A humanist science of the rule of law worth its salt would, along the lines of what Theunis Roux writes about Krygier's own work in his essay, have to be at once normatively inflected and sociologically aware. Indeed, for Krygier it would start with normative questions. This is why he has been at pains to point out that his is not a "sociological research agenda" on the rule of law' as such, but a philosophically directed inquiry that begins with norms and turns to facts. ${ }^{56}$ It is also why he has advocated both for "sociological concern with the rule of law and lawyerly concern with sociology,. ${ }^{57}$ This is not another way of repeating an old refrain that we need more social science in law, or more lawyers doing empirical legal scholarship. It is more like Krygier wants lawyers to practice thinking about the rule of law in the manner of sociologists, who are his proxy social scientists, regardless of whether they have trained in sociology or do social scientific research. And by the same token, today's social scientists, whom Krygier addresses in the closing pages of the Selznick book, shouldn't have to go to law school to learn a thing or two from lawyers about the importance of norms.

Secondly, Selznick refused to limit the rule of law's scope to public law and the state. His question in Law, Society, and Industrial Justice was: how could the rule of law be extended to the relation between employers and employees in large organizations? Krygier's subject has throughout been 'the restraint of power through law'. ${ }^{58}$ But whereas early on his problem was framed in relation to the power of government, latterly he has spoken and written of the general exercise of power as the distinctive domain of the rule of law, and the arbitrary exercise of power as its specific antipathy, arguing that the ideal 'should be understood as extending... not merely to official laws and other acts of state but to exercises of substantial power writ large,

53 Ibid., p. 136.

54 Quoted in ibid., p. 135.

55 Krygier (2009), p. 46.

56 Krygier (2013).

57 Ibid., p. 51.

58 Krygier (1990a), p. 646. 
whether that be by the state or other actors'. ${ }^{59}$ As sources of arbitrary power are many, governmental power cannot be the rule of law's only target. Under some circumstances it might not be the main one. In his essay, Palombella explores the influence of epistemic authorities as a particularly salient example of this point.

Thirdly, Selznick insisted that the rule of law is not just about reducing, preventing, limiting or curbing the exercise of power. It is not only a negative value. It is also an affirmative one. It enables law to realize its potential by encouraging people to make use of it in a variety of ways. This affirmative quality is, partly, what Selznick meant when he described the rule of law as 'progressive' in character. It is what makes it an ideal in the world. That is why it can be institutionally embodied. However, because it is an ideal it can never be fulfilled. Like other ideals it is an aspiration that 'informs the concrete goals we set before us, but [that] ought not be confused with those goals' ${ }^{60}$ That is why failure to reach the rule-of-law ideal is not cause for despair. Although this idea is already present in Krygier's writing on the rule of law before the 2010s, following Ideals in the World it has more deeply informed his work on what the rule of law is good for than it did previously.

\section{Teleology, Anatomy, Sociology}

Martin Krygier's theory of the rule of law post-revival, so to speak, has three levels: normative, sociological, and legal. They are reached by way of tripartite questions: the why, what or where, and how of the rule of law; that is, by asking after the ends of the rule of law; then after the conditions which legal rules and institutions must satisfy; and finally after the means, which is to say, where lawyers usually begin, with the contents of these legal rules and institutions themselves. The order in which we ask the questions matters. 'I advocate starting,' Krygier says, 'with the ends of the rule of law, rather than what purports to be its institutional anatomy' ${ }^{61}$ Only once ends are clarified does it make sense to talk about what might be done to move towards them.

While Krygier works across three levels, he has concentrated on the normative and sociological: the why and what or where of the rule of law. He has not attempted to add much to the how. He has disavowed a certain amount of responsibility for it in his own work, on grounds that he has neither sufficient experience nor inclination to address this question as fully as the others. Anyway, in his view the why and what or where questions tend to be overlooked in the rush to come up with how-to answers to rule-of-law problems. Or the questions become entangled. Among the 'follies of institutional craftsmanship' that worry Krygier are a tendency to conflate ends and means, to treat the why as self-evident from attending to the how. ${ }^{62}$ These follies also have brought Krygier around to the view that rule-of-law laundry lists

\footnotetext{
59 Krygier (2017a), p. 317; see Krygier (2018b).

60 In Krygier (2012), p. 40.

61 Krygier (2009), p. 57.

62 Krygier and Mason (2008), p. 3.
} 
like 'Fuller's octet, or Dicey's trio, or the World Bank's Rule of Law recipe book' are at best unreliable guides for whether or not a society has the rule of law. ${ }^{63}$ Why? The general answer to that question is that the questions we choose to ask affect the answers we get. The more specific answer is that the answers that Krygier gets to the questions he chooses to ask about the rule of law, and the sequence in which he asks them, are different to the answers that Fuller, Dicey or the World Bank get to their chosen questions.

To be clear, Krygier's question about the rule of law's immanent point or telos is different from those generally concerned with potential extrinsic ends or societal benefits, such as economic development or postconflict stability. It is a more fundamental question about what the rule of law is for. This is the topic of a number of essays in this Special Issue. Those by Jeff King and Wojciech Sadurski critically examine and suggest further development of the teleological plank in Krygier's theory. Rosalind Dixon and András Sajó explain its importance in times of abusive constitutionalism, with the latter posing the tantalizing question of whether the rule of law inevitably has disastrous consequences. Richard Sannerholm, Christopher May and Deval Desai point to its significance for rule of law promotion. Anna ŚledzińskaSimon and Petra Bárd demonstrate the efficacy of a teleological approach to the rule of law through their inquiry into European Union infringement action concerning judicial independence in Poland. Dimitry Kochenov criticizes the European Commission for failing to understand the telos of the rule of law in both its diagnosis and its solutions to the current rule of law crisis in Hungary and Poland.

For his part, Krygier has consistently argued that the rule of law's telos consists in the reduction of possibilities to exercise power arbitrarily. To repeat, this is not at all an original argument. Nor did he ever claim it was. He has emphasized that the point of the rule of law is 'commonly understood' to be anti-arbitrariness. ${ }^{64}$ But what is that? For some time Krygier admitted that, like Selznick, he was 'uncomfortably conscious' that he was 'yet to provide a satisfactory and sufficiently complex and textured analysis of what arbitrariness includes... and excludes'. ${ }^{65}$ Through dialogue with contemporary theorists he has somewhat clarified and developed this aspect of his theory. In 2011 he adopted and amplified Philip Pettit's well-known definition of arbitrariness as an adequate general expression of the rule of law's immanent value, inspired by Palombella's work on the rule of law as an institutional ideal. ${ }^{66}$ According to Pettit, whose essay in this Special Issue is about whether the rule of law existed in ancient Athens,

An act is perpetrated on an arbitrary basis, we can say, if it is subject just to the arbitrium, the decision or judgement, of the agent; the agent was in a position to choose it or not choose it, at their pleasure. When we say that an act of interference is perpetrated on an arbitrary basis... we imply that it is chosen or

\footnotetext{
63 Krygier (2011b), p. 68.

64 Krygier (2004), p. 257.

65 Krygier (2009), p. 57.

66 Krygier (2010).
} 
rejected without reference to the interests, or the opinions, of those affected.

The choice is not forced to track what the interests of those others require according to their own judgements. ${ }^{67}$

This, Krygier argued, includes situations where laws are applied without offering people a chance to express or explain themselves - that "crucial dignitarian idea' integral to working conceptions of the rule of law about which Waldron has written. ${ }^{68}$

In his latest Annual Review essay, Krygier has offered a non-exhaustive typology of arbitrariness: one type being 'where power-wielders are not subject to routine, regular control or limit'; another which is the stuff of philosophers' laundry lists, when those people whom power 'affects cannot know, predict, understand, or comply' with it; and a further one, where there is no space or means available for people who power affects 'to be heard, to question, to inform, or to affect the exercise of power over them'. 69 These he has since summarized as uncontrolled, unpredictable and unrespectful power. ${ }^{70}$ Although various traditions of thought have addressed all three types, Krygier says that these traditions tend to elide one or another type. But arbitrariness works across all three. We need to see each of its types in relation to the others to make sense of it, for two reasons: first, because contrary to the scorecard approach to the rule of law, in which an aggregate figure is what determines a society's ranking on a rule-of-law league table and a low score on one type can be offset by a high score on another, a society needs to do reasonably well on all three to claim the rule of law's mantle; and, secondly, because a society might need to do different things about one or another type in order to temper power effectively. The path away from arbitrariness does not run straight. It is not even one path.

The other question Krygier has addressed at length is: which conditions do rules and institutions need to fulfil so as to work towards the rule of law's telos? His answers to this question can give a misleading impression of what he is up to. Starting with his piece on 'Transitional Questions' in 2001, Krygier has found fault with conventional rule-of-law accounts, variously criticizing the parochialism, unhelpfulness and narrowness of what Waldron has called laundry lists of demands. ${ }^{71}$ Moreover, he has said that the rule of law rests on non-legal mechanisms and institutions, and that law often has 'a negligible role'. ${ }^{72}$ It may appear from this that Krygier's rule of law is a political ideal that has a lot to do with rule but little, if anything, with law.

But appearances can be deceptive. Elsewhere Krygier has maintained, with Raz, that the concept "needs to have a special connection with law, lest the rule of law come to mean the rule of whatever is good, in which case we have no need for the concept'. ${ }^{73}$ Krygier's is neither the rule of the good nor the rule of good law. Nor is

\footnotetext{
67 Pettit (1997), p. 55.

68 See Waldron (2011), p. 16.

69 Krygier (2016b), pp. 203-204.

70 Krygier (2019).

71 Waldron (2011), p. 5.

72 Krygier (2018b), p. 151.

73 Krygier (2011b), p. 81.
} 
it a 'good enough' rule of law for particularistic goals: a legalistic instrument for the kind of fast economic growth absent of measures to restrain arbitrary power that Fukuyama has contemplated. ${ }^{74}$ It is the rule of law for a good society, a rule of law that with Krygier himself has 'the right combination of demanding yet anti-perfectionist ambition'. ${ }^{75}$ A really existing good society will always have recourse to law so as to impede arbitrariness. In a close reading of Palombella in which he iterates Pettit's stress on how 'to enjoy non-domination is... to be possessed, not just of noninterference by arbitrary powers, but of a secure and resilient variety of such noninterference', Krygier underlines that law is indispensible to this task. ${ }^{76}$

This is not mere lip service to law within a body of work otherwise taken up with the rule of law's social qualities. On the contrary, it reflects what Krygier has been saying for a long time. Almost two decades ago he identified and described four conditions of the rule of law: scope, which concerns equality before law, especially as this principle pertains to those in power; character, which denotes that people can be guided by law, through laws that are known, public, understandable, prospectively applied and stable; serious administration, interpretation and enforcement of law; and, finally, the social reach and weight of law, which means that law actually counts in society - that it is used and invoked; applied by citizens, officials and corporate bodies alike. $^{77}$

Throughout the 2000s Krygier continued to refer to these four conditions for the rule of law's what or where. In his 'Four Puzzles about the Rule of Law' the quartet became a trio, namely: formal characteristics of law, that is to say, something like Fuller's desiderata; procedural elements guaranteeing that people are treated with the dignity they deserve as beings able to explain themselves, pointing to Waldron's work on the importance of procedure; and a duality in positive law so that law made by the powers-that-be is constrained by a higher yet positive set of laws beyond their reach, exemplified in Palombella's institutional ideal. ${ }^{78}$ Each of these three versions, Krygier wrote, 'captures a significant way in which law might contribute to the rule of law and also represents a significant strand in distinguished traditions of thinking about the rule of law and how it is to be made good'. ${ }^{79}$

So Krygier has never rejected traditional accounts of the rule of law's desiderata. The point of his criticism is just that they cannot get us far. Taken further than they can get us, they might not get us anywhere at all. Similar rules and institutions may have different effects in different societies. Those that may contribute to the rule of law in some places may have no significant effect or even undermine it in others. Judicial independence is a case in point. Where it shields capable judges against executive overreach, that's one thing, and the thing for which it is touted. Where it makes immovable 'old, incompetent, corrupt, badly formed hold-overs from earlier

\footnotetext{
74 Fukuyama (2011).

75 Krygier (1999), p. 20.

76 Pettit (1997), p. 69, in Krygier (2014b), p. 91.

77 Krygier (2001a)

78 Krygier (2011b), pp. 81-85.

79 Ibid., p. 84.
} 
times', as in Poland and Bulgaria, it's another thing altogether. ${ }^{80}$ Conversely, there may be alternative legal or non-legal rules and institutions that enhance the rule of law's value. Law on the books that ticks some boxes in conventional rule-of-law accounts might minimally reduce arbitrary exercises of power, or it might strengthen them. Non-legal values and institutions might be more effective than legal ones in reducing arbitrariness.

To recap, by Krygier's lights the rule of law is both a legal and social achievement. The problem of how to embody values that sustain it in institutions to defend it is as much a legal problem as it is a sociological one, which is why Kim Lane Schepelle in her contribution characterizes Krygier as 'a social theorist with a keen eye for how the law actually works in practice'. Jiř́ Přibáň's essay in this Special Issue takes up this problem theoretically in its discussion of constitutional values. Richard Abel's graphically illustrates it through an inquiry into the rule of law's fate during the so-called war on terror, as does Jothie Rajah's foray into extraterritorial power in American empire, prompted by Krygier's maxim that 'if there were ever a subject that could benefit from historical awareness and interdisciplinary mixing, it is the rule of law'. ${ }^{81}$ Each of these authors would seem to agree broadly with Krygier that the rule of law is relative and variable in its successes and failures, observable where power is constrained and arbitrariness minimized, both as a matter of legal principle and through social practice.

\section{Tempering Power (and Beyond?)}

In his most recent work, Martin Krygier has talked of how the rule of law tempers power. He has even promised a book under the rubric of Tempering Power, subtitled 'beyond the rule of law'. ${ }^{82}$ We eagerly await it. For now we have a chapter or two on the subject, and Krygier's remarks on the same in his 2017 Dennis Leslie Mahoney Prize Lecture, from which Halliday has drawn for his essay. ${ }^{83}$

Why tempering power? If power's presence has been manifest throughout these pages, as it has been throughout Krygier's work, then the tempering impulse has doggedly shadowed it. Tempering power is not new to Krygier's thinking, even if it is a novel way of more precisely capturing ideas that have been percolating through it for these past three decades-ideas for which Krygier again owes a debt to Selznick, as well as Stephen Holmes, from whom he has learned much in diagnosing post-communist transformations in Central and Eastern Europe, and on the rule of law as both positive and negative virtue.

Temperance is, and since ancient times has been, a positive virtue. It entails restraint, but also a sense of self-awareness, one that institutions embodying the rule of law have. It is less about limiting power than about harnessing it for good.

\footnotetext{
${ }^{80}$ Krygier (2006), p. 144.

81 Krygier (2016b), p. 222.

82 Krygier (2018b), p. 146.

83 Krygier (2017b).
} 
Krygier has long written against ideologically-driven projects aimed at minimizing state power to regulate and redistribute. He has celebrated the moments of greatest liberal democratic success last century, contra Hayek, as moments when the welfare state was at its height: at once liberal, social and democratic. ${ }^{84}$ And, we might add, civil. His International-with-adjectives is among other things communitarian and social, after the conservative-liberal-socialism that Leszek Kolakowski once proposed. ${ }^{85}$ So tempering power recommends itself as a way of getting at values immanent to the rule of law that Krygier wants to foreground; values that might be useful for thinking about why we would want the rule of law at all.

In tempering power, Krygier's rule of law does not shackle government's legs; it ushers them along paths towards things that government should do, away from things it should not. Does this analogy to routes along which a government might travel towards some end or ends suggest that its members must always choose between this or that branch? No. Of course, there are always trade-offs, among values, and other things besides. That is why debates about the rule of law matter. Krygier says as much, often enough. Trade-offs sometimes call for hard choices. But frequently hard choices appear to us as false choices: between compatible ideals that seem antagonistic, between complementary strategies that seem divergent. Which is why Martin is fond of quoting Yogi Berra: when you reach a fork in the road, take it.

As these introductory remarks in appreciation of Martin Krygier and his virtues reach not another fork in their road but instead arrive at their inevitable terminus, where have we come to? Not, for sure, at a definitive statement on the rule of law to be yet more grist for the mills of legal philosophers; nor, for that matter, with one to serve as measuring tape for rule-of-law technicians. But we offered neither, because Martin hasn't either. If he is still a rule of law guy it is not because finely crafted definitions or beautifully designed instruments matter greatly to him, but because of his ardent concern for 'the value of the rule of law in life'. ${ }^{86}$ Krygier's is neither a philosopher's nor a technician's rule of law. It is, with and after Selznick's, a humanist one. It is, as Julian Sempill has put it in his essay, a rule of law that is guided along with Martin himself 'by a humanist sensibility that is willing to let concern for concrete human experience get in the way of a good theoretical story'. It is this tempering of theory by sensibility that is among Martin Krygier's foremost virtues. And it is among those that we most appreciate.

Open Access This article is distributed under the terms of the Creative Commons Attribution 4.0 International License (http://creativecommons.org/licenses/by/4.0/), which permits unrestricted use, distribution, and reproduction in any medium, provided you give appropriate credit to the original author(s) and the source, provide a link to the Creative Commons license, and indicate if changes were made.

\footnotetext{
84 Krygier (2018a).

85 Krygier (2002).

86 Krygier (2013), p. 52.
} 


\section{References}

Abel R (1990) Capitalism and the rule of law: precondition or contradiction? Law Soc Inq 15(4):685-697

Carothers T (1998) The rule of law revival. Foreign Affairs 77(2):95-106

Coleman P (1986) The prodigal sons: the unlikely story of Richard Krygier and the Australian Association for Cultural Freedom. Quadrant 30(11):10-21

Comaroff J (1990) Re-Marx on repression and the rule of law. Law Soc Inq 15(4):671-678

Czarnota A, Krygier M, Sadurski W (2005) Rethinking the rule of law after communism. Central European University Press, New York

Czarnota A, Krygier M, Sadurski W (2006) Spreading democracy and the rule of law? The impact of EU enlargement for the rule of law, democracy and constitutionalism in post-communist legal orders. Springer, Dordrecht

Dworkin R (1985) Political judges and the rule of law. In: A matter of principle. Harvard University Press, Cambridge

Fehér F, Heller A, Márkus G (1983) Dictatorship over needs. Blackwell

Fukuyama F (2011) The origins of political order: from prehuman times to the French revolution. Straus and Giroux, New York

Krygier M (1983) Marxism and law, by Hugh Collins. UNSW Law J 6(2):238-246

Krygier M (1986) Law as tradition. Law Philos 5(2):237-262

Krygier M (1990a) Marxism and the rule of law: reflections after the collapse of communism. Law Soc Inq 15(4):633-663

Krygier M (1990b) Marxism, communism, and narcissism. Law Soc Inq 15(4):707-730

Krygier M (1997a) Hybrids and comparisons. ABC Radio National. https://www.abc.net.au/radionatio nal/programs/boyerlectures/lecture-1-hybrids-and-comparisons/3460228. Accessed 7 Sept 2015

Krygier M (1997b) Pride, shame and decency. ABC Radio National. https://www.abc.net.au/radionatio nal/programs/boyerlectures/lecture-4-pride-shame-and-decency/3460216. Accessed 7 Sept 2015

Krygier M (1999) A good society. Eureka Street 9:20-23

Krygier M (2001a) Transitional questions about the rule of law: why, what, and how? East Central Europe/L'Europe du Centre-Est. Eine wissenschaftliche Zeitschrift 28(1):1-34

Krygier M (2001b) The rule of law (and Rechtsstaat). In: Smelser NJ, Baltesin PB (eds) International encyclopedia of the social and behavioral sciences. Elsevier

Krygier M (2002) Conservative-liberal-socialism revisited. Good Soc 11(1):6-15

Krygier M (2004) False dichotomies, true perplexities, and the rule of law. In: Sajó A (ed) Human rights with modesty: the problem of universalism. Martinus Nijhoff Publishers, Leiden

Krygier M (2005a) Civil passions: selected writings. Black Inc., Melbourne

Krygier M (2005b) Rethinking the rule of law after communism. In: Czarnota A, Krygier M, Sadurski W (eds) Rethinking the rule of law after communism. Central European University Press, New York

Krygier M (2006) The rule of law: an abuser's guide. In: Sajó A (ed) Abuse: the dark side of fundamental rights. Eleven International Publishing, The Hague

Krygier M (2009) The rule of law: legality, teleology, sociology. In: Palombella G, Walker N (eds) Relocating the rule of law. Hart, Oxford

Krygier M (2010) Philip Selznick's humanist science. Law Courts Newsl Law Courts Sect Am Polit Sci Assoc 20(2): 14

Krygier M (2011a) The meaning of what we have done: humanity, invisibility and law in the European settlement of Australia. In: Cordner C (ed) Philosophy, ethics and a common humanity: essays in honour of Raimond Gaita. Routledge, London

Krygier M (2011b) Four puzzles about the rule of law: why, what, where? And who cares? In: Fleming JE (ed) Getting to the rule of law, Nomos. New York University Press, New York

Krygier M (2012) Philip Selznick: ideals in the world. Stanford University Press, Stanford

Krygier M (2013) Still a rule of law guy. Recht der Werkelijkheid 34(1):47-55

Krygier M (2014a) An intimate and foreign affair. In: Curthoys A, Damousi J (eds) What did you do in the Cold War, daddy? Personal stories from a troubled time. NewSouth, Sydney

Krygier M (2014b) Inside the rule of law. Rivista di Filosofia del Diritto 3(1):77-98

Krygier M (2016a) The rule of law between England and Sudan: Hay, Thompson, and Massoud. Law Soc Inq 41(2):480-488

Krygier M (2016b) The rule of law: pasts, presents, and two possible futures. Ann Rev Law Soc Sci 12:199-229 
Krygier M (2017a) Legal pluralism and the value of the rule of law. In: Roughan N, Halpin A (eds) Pursuit of pluralist jurisprudence. Cambridge University Press, Cambridge

Krygier M (2017b) Tempering power. In: Adams M, Meuwese A, Ballin EH (eds) Constitutionalism and the rule of law. Cambridge University Press, Cambridge

Krygier M (2018a) Transformations of the rule of law: legal, liberal, and neo-. In: Golder B, McLoughlin $\mathrm{D}$ (eds) The politics of legality in a neo-liberal age. Routledge, London

Krygier M (2018b) Why the rule of law matters. Jurisprudence 9(1):146-158

Krygier M (2019) The rule of law and state legitimacy. In: Sadurski W, Sevel M, Walton K (eds) Legitimacy: the state and beyond. Oxford University Press, Oxford

Krygier M, Mason W (2008) Violence, development and the rule of law. UNSW Law Res Pap 8:3

Margalit A (1996) The decent society. Harvard University Press, Cambridge

Nonet P, Selznick P (2001) Law and society in transition: toward responsive law. Transaction Publishers, New Brunswick (repr., 2001)

Palombella G (2010) The rule of law as an institutional ideal. In: Morlino L, Palombella G (eds) Rule of law and democracy: inquiries into internal and external issues, International Studies in Sociology and Social Anthropology Series. Brill, Leiden

Pettit P (1997) Republicanism: a theory of freedom and government. Oxford University Press, Oxford

Raz J (1979) The rule of law and its virtue. In: The authority of law: essays on law and morality. Clarendon Press, Oxford

Ryckmans P (1996) The view from the bridge: aspects of culture, Boyer lectures. ABC Books, Sydney

Selznick P (1949) TVA and the grass roots: a study in the sociology of formal organization. University of California Press, Berkeley

Selznick P (1969) Law, society, and industrial justice. Russell Sage, New York

Selznick P (1992) The moral commonwealth: social theory and the promise of community. University of California Press, Berkeley

Tamanaha BZ (2011a) The rule of law and legal pluralism in development. Hague J Rule Law. 3(1):1-17

Tamanaha BZ (2011b) The primacy of society and the failures of law and development. Cornell Int Law J 44(2):209-247

Waldron J (2011) The rule of law and the importance of procedure. In: Fleming JE (ed) Getting to the rule of law, Nomos. New York University Press, New York

Publisher's Note Springer Nature remains neutral with regard to jurisdictional claims in published maps and institutional affiliations. 